\title{
PENGARUH KEGEL EXERCISE TERHADAP INKONTINENSIA URINE PADA IBU POSTPARTUM MULTIPARA
}

\author{
Murti Sari Ningsih ${ }^{1 *}$, Erika ${ }^{1}$, Rismadefi Woferst ${ }^{1}$ \\ ${ }^{1}$ Fakultas Keperawatan Universitas Riau, Pekanbaru, Indonesia \\ murtisari49@gmail.com
}

\begin{abstract}
Introduction: One of problems experienced post-partum mothers is urine incontinence. Kegel exercise effects on urine incontinence post-partum mothers and elderly. However, limited study search for its effect on multiparous post-partum mothers. This study aims to determine the effect of Kegel exercise on urinary incontinence in multiparous post-partum mothers.

Methods: The research design used was a quasi-experiment with a post-test with control group design which was divided into an experimental group and a control group. The research was conducted in the work area of Rejosari Public Health Center with a sample size of 34 respondents with the criteria of multiparous postpartum mothers who experienced urinary incontinence in normal labor with a purposive sampling technique. The measuring instrument used was the International Consultation on Incontinence Questionnaire Short Form (ICIQ-SF). Data analysis used dependent and independent ttest.

Results: The results of the dependent t-test statistic with $\alpha 0.05$ showed that Kegel exercise was effective against urinary incontinence in the experimental group $p$ value (0.000) and the control group $p$ value (0.033) and the results of the independent t-test showed that there was an effect of Kegel exercise on urinary incontinence in the experimental group and the control group $p$ value (0.004). The results of this study can be used as a reference for using Kegel exercises as a way to deal with complaints of urinary incontinence in multiparous post-partum mothers.
\end{abstract}

Key words: Kegel Exercises, Urinary Incontinence, Postpartum Multipara.

\begin{abstract}
Abstrak
Pendahuluan: Salah satu gangguan yang dialami pada ibu postpartum yaitu inkontinensia urine. Latihan Kegel berpengaruh terhadap inkontinensia urine pada ibu postpartum dan lansia. Penelitian terkait pengaruh inkontinensia terhadap ibu postpartum multipara masih terbatas. Penelitian ini bertujuan untuk mengetahui Pengaruh Kegel exercise terhadap inkontinensia urine pada ibu post-partum multipara.

Metode: Desain penelitian yang digunakan quasi experiment dengan rancangan post-test with control group. Penelitian dilakukan di wilayah kerja Puskesmas Rejosari jumlah sampel 34 responden dengan kriteria ibu postpartum multipara yang mengalami inkontinensia urine persalinan normal dengan teknik purposive sampling. Alat ukur yang digunakan adalah International Consultation on Incontinence Questionnaire Short Form (ICIQ-SF). Analisa data yang digunakan dependent dan independent t-test.

Hasil: Hasil dependent t-test menunjukkan Kegel exercise berpengaruh terhadap inkontinensia urine pada kelompok experiment $p$ value $(0,000)$ maupun kelompok kontrol $p$ value $(0,033)$ dan hasil independent $t$-test didapatkan bahwa ada pengaruh Kegel exercise terhadap inkontinensia urine pada kelompok experiment dan kontrol $p$ value $(0,004)$. Hasil penelitian ini dapat dijadikan sebagai bukti dasar untuk menggunakan Kegel exercise sebagai salah satu cara untuk mengatasi keluhan inkontinensia urine pada ibu postpartum multipara.
\end{abstract}

Kata kunci: Kegel Exercise, Inkontinensia Urine, Postpartum Multipara. 


\section{PENDAHULUAN}

Salah satu gangguan yang dialami pada wanita khususnya ibu postpartum yaitu gangguan sistem perkemihan. Diantara gangguan sistem perkemihan tersebut yaitu inkontinensia urine (Ambarwati, 2010). Data World Health Organization/WHO (2016) menunjukkan bahwa 200 juta penduduk mengalami inkontinensia urine. Terdapat 13 juta penduduk Amerika Serikat menderita inkontinensia urine dan $85 \%$ diantaranya adalah perempuan. Kasus inkontinensia urine di Indonesia sangat signifikan. Tahun 2016, diperkirakan 5,8\% dari jumlah penduduk mengalami inkontinensia urine (Departemen Kesehatan Republik Indonesia [Depkes RI], 2016). Sebanyak 62 ibu postpartum mengalami inkontinensia urine, dan tahun 2018 terdapat 55 ibu mengalami inkontinensia urine dengan riwayat persalinan normal (Puskesmas Rejosari, 2017). Karjoyo (2017) menerangkan bahwa sebagian besar responden yang mengalami inkontinensia urine pada post persalinan normal/pervaginam, serta hampir $50 \%$ wanita yang pernah melahirkan tersebut menderita prolaps organ genitourinaria dan $40 \%$ disertai inkontinensia urine (Ambarwati, 2010).

Inkontinensia urine terjadi karena peningkatan vaskularisasi ke organ-organ pelvis, juga mempengaruhi kegiatan ginjal seperti frekuensi berkemih yang lebih sering. Peningkatan suplai darah ke ginjal dan ureter juga menyebabkan terjadinya dilatasi karena adaptasi dari sel-sel glumerulus ginjal dan ureter. Frekuensi buang air kecil (BAK) yang sering juga disebabkan karena penekanan kandung kemih atau uterus dan saat penurunan janin kerongga panggul. Tekanan yang sering terjadi secara berulang-ulang dapat melemahkan otot dasar panggul sehingga terjadi inkontinensia urine (Bobak, Lowdermilk, \& Jensen, 2011).
Penanganan untuk inkontinensia urine bisa dilakukan diantaranya yaitu dengan latihan otot dasar panggul (Kegel Exercise), bladder training, penggunaan alat-alat eksternal, modifikasi pengobatan dan pembedahan. Salah satu teknik yang dapat digunakan mencegah dan mengatasi inkontinensia urine adalah Kegel exercise (Ambarwati, 2010).

Kegel exercise adalah latihan untuk membantu memperkuat otot dasar panggul (Please, 2017). Latihan Kegel pada awalnya dikembangkan sebagai metode untuk mengendalikan inkontinensia urine pada wanita setelah melahirkan. Kegel exercise ini bertujuan untuk memperkuat otot periuretra dan perivaginal sehingga ibu mampu mengontrol pengeluaran kemih secara maksimal sehingga masalah-masalah yang disebabkan oleh inkontinensia urine dapat teratasi (Purnomo, 2011).

Achirda (2016) menjelaskan bahwa dengan perlakuan kombinasi biofedback dan Kegel exercise diperoleh peningkatan kekuatan otot dasar panggung pada inkontinensia urine tipe stress pasca partus normal. Cafkaytar (2014) menerangkan bahwa wanita pada kelompok Stress Urine Incontinencia (SUI) dan wanita pada kelompok Mised Urine Incontinencia (MIU) mengalami perbaikan yang signifikan secara statistik. Penelitian tersebut menunjukkan latihan Kegel berbasis rumah, tanpa pengawasan efektif dalam menurunkan stress urine incontinencia dan mised urine incontinencia pada wanita.

Tingginya angka kejadian inkontinensia urine menyebabkan perlunya penanganan yang sesuai, karena jika tidak segera ditangani dapat menyebabkan berbagai komplikasi seperti infeksi saluran kemih, infeksi kulit daerah kemaluan, gangguan tidur, dan gejala ruam. Selain itu, masalah psikososial seperti dijauhi orang lain karena 
berbau pesing, minder, tidak percaya diri, mudah marah juga sering terjadi dan hal ini berakibat pada depresi dan isolasi sosial (Stanley \& Beare, 2007). Penelitian ini menggunakan tehnik Kegel Exercise untuk mengatasi inkontinensia urine pada ibu psot partum, karena gerakan kegel exercise ini dapat memperkuat otot periuretra dan perivaginal sehingga ibu mampu mengontrol pengeluaran kemih secara maksimal sehingga masalah-masalah yang disebabkan oleh inkontinensia urine dapat teratasi (Purnomo, 2011).

Latihan Kegel berpengaruh terhadap inkontinensia urine pada ibu postpartum dan lansia. Penelitian terkait pengaruh inkontinensia terhadap ibu postpartum multipara masih terbatas. Tujuan penelitian ini adalah untuk mengetahui pengaruh kegel exercise terhadap inkontinensia urine pada ibu postpartum multipara. Hasil penelitian ini diharapkan dapat menjadi referensi dan acuan dalam penatalaksanaan inkontinensia urine pada ibu postpartum dan dapat dijadikan salah satu intervensi dalam asuhan keperawatan.

\section{METODE}

Penelitian ini dilakukan di wilayah kerja Puskesmas Rejosari yang dilakukan pada bulan November-Desember 2019. Penelitian ini merupakan penelitian kuantitatif dengan desain penelitian quasi experiment dengan post-test with control group. Penelitian ini melibatkan dua kelompok yaitu kelompok 1 (perlakuan) dan kelompok 2 (kontrol).

Populasi penelitian ini adalah ibu postpartum multipara dengan inkontinensia urine. Sampel penelitian ini adalah ibu postpartum 3 sampai 5 hari paska melahirkan. Pengambilan sampel pada menggunakan teknik purposive sampling. Besar sampel sebanyak 34 ditentukan dengan rumus berikut:

$$
n^{\prime}=\frac{n}{(1-L)}
$$

Keterangan:

$n^{\prime}=$ ukuran sampel setelah revisi

$n$ = besar sampel yang dihitung

$\mathrm{L}=$ perkiraan proporsi drop out, yang diperkirakan $10 \%(\mathrm{~L}=0,1)$

$n^{\prime}=\frac{30}{(1-0,1)}$

$n^{\prime}=33,33$ (34 responden).

Instrumen yang digunakan adalah International Consultation on Incontinence Questionnaire Short Form (ICIQ-SF).

Analisis data menggunakan analisis univariat dan bivariat. Analisis data univariat mendeskripsikan karakteristik responden meliputi usia, pendidikan dan jenis pekerjaan.

Analisis bivariat digunakan untuk melihat pengaruh Kegel exercise terhadap inkontinensia urine pada kelompok perlakuan dan kontrol. Hasil penelitian dikatakan terdapat pengaruh jika $p$ value $<(0,05)$. Analisis data yang digunakan untuk membedakan rata-rata inkontinensia urine kelompok perlakuan dan kelompok kontrol pre dan post-test menggunakan dependent t-test, sedangkan untuk mengetahui perbedaan ratarata inkontinensia urine post-test antara kelompok perlakuan dengan kelompok kontrol menggunakan independent t-test.

\section{HASIL PENELITIAN}

Tabel 1. Distribusi Frekuensi Karakteristik Responden $(\mathrm{n}=34)$

\begin{tabular}{lcc}
\hline \multicolumn{1}{c}{ Karakteristik } & Jumlah & $\%$ \\
\hline Kelompok Usia & & \\
$<20$ & - & - \\
$20-35$ & 15 & 44,1 \\
$>35$ & 19 & 55,9 \\
\hline Pendidikan & & \\
Dasar & 14 & 41,2 \\
Menengah & 14 & 41,2 \\
Perguruan Tinggi & 6 & 17,6 \\
\hline Jenis Pekerjaan & & \\
PNS & 3 & 8,8 \\
Swasta & 6 & 17,7 \\
Ibu Rumah Tangga & 25 & 73,5 \\
\hline
\end{tabular}


Tabel 1 menunjukkan bahwa mayoritas usia responden adalah pada usia $<35$ tahun (55,9\%), sebagian besar adalah pendidikan dasar dan pendidikan menengah dengan jumlah masing-masing $41,2 \%$, dan sebagian besar adalah ibu rumah tangga $(73,5 \%)$.

Tabel 2. Rata-rata Inkontinensia Urine Sebelum dan Sesudah Kegel Exercise pada Kelompok Perlakuan $(\mathrm{n}=34)$

\begin{tabular}{ccrrrr}
\hline $\begin{array}{c}\text { Inkontinensia } \\
\text { urine }\end{array}$ & $\mathrm{N}$ & Mean & SD & Min & Max \\
\hline Pre-test & 17 & 12,18 & 3,957 & 6,00 & 19,00 \\
\hline Post-test & 17 & 9,29 & 2,779 & 4,00 & 13,00 \\
\hline
\end{tabular}

Tabel 2 menunjukkan nilai mean inkontinensia urine sebelum Kegel exercise pada kelompok perlakuan adalah 12,8 dengan skor minimal 6,00 dan skor maksimal 19,00 serta standar deviasi 3,957. Nilai mean posttest adalah 9,29 dengan skor minimal 4,00 dan skor maksimal 13,00 serta standar deviasi 2,779 .

Tabel 3. Rata-rata Inkontinensia Urine Pre dan Post-Test Tanpa Kegel Exercise Kelompok Kontrol

\begin{tabular}{cccccc}
\hline $\begin{array}{c}\text { Inkontinensia } \\
\text { urine }\end{array}$ & $\mathrm{N}$ & Mean & $\mathrm{SD}$ & $\mathrm{Min}$ & $\mathrm{Max}$ \\
\hline Pre test & 17 & 11,12 & 2,288 & 7,00 & 16,00 \\
\hline Post test & 17 & 11,88 & 1,996 & 8,00 & 16,00 \\
\hline
\end{tabular}

Tabel 3 menjelaskan bahwa mean pre test inkontinensia urine pada kelompok kontrol adalah 11,12 dengan skor minimal 7,00 dan skor maksimal 16,00 serta standar deviasi 2,288. Sedangkan mean pre test inkontinensia urine adalah 11,88 dengan skor minimal 8,00 dan skor maksimal 16,00 serta standar deviasi 1,996 .
Tabel 4. Rata-rata Frekuensi Inkontinensia Urine pada Kelompok Perlakuan dan Kontrol Pre dan Post-test

\begin{tabular}{|c|c|c|c|c|c|}
\hline $\begin{array}{c}\text { Kelo } \\
\text { mpo } \\
\text { k }\end{array}$ & $\begin{array}{l}\text { Inkontine } \\
\text { nsia urine }\end{array}$ & Mean & $\begin{array}{c}\text { Peruba } \\
\text { han } \\
\text { Mean }\end{array}$ & SD & $\begin{array}{c}p \\
\text { value }\end{array}$ \\
\hline $\begin{array}{c}\text { Exsp } \\
\text { erim } \\
\text { ent }\end{array}$ & $\begin{array}{l}\text { Pre test } \\
\text { Post test }\end{array}$ & $\begin{array}{r}12,18 \\
9,29\end{array}$ & 2,89 & $\begin{array}{l}3,957 \\
2,779\end{array}$ & $\begin{array}{c}0,00 \\
0\end{array}$ \\
\hline $\begin{array}{c}\text { Kont } \\
\text { rol }\end{array}$ & $\begin{array}{l}\text { Pre test } \\
\text { Post test }\end{array}$ & $\begin{array}{l}11,12 \\
11,88\end{array}$ & 0,76 & $\begin{array}{l}2,288 \\
1,996\end{array}$ & $\begin{array}{c}0,03 \\
3\end{array}$ \\
\hline
\end{tabular}

Tabel 4 menjelaskan perubahan mean antara sebelum dan sesudah pemberian Kegel exercise pada kelompok perlakuan adalah 2,89 dan didapatkan $p$ value $=0,000<\alpha 0,05$. Hal ini dapat disimpulkan bahwa terdapat pengaruh yang signifikan antara inkontinensia urine pre dan post-test dengan pemberian Kegel exercise. Perubahan mean antara sebelum dan sesudah pada kelompok kontrol adalah 0,76 dan didapatkan $p$ value $=0,033<$ $\alpha$ 0,05 sehingga dapat disimpulkan bahwa terdapat pengaruh yang signifikan antara inkontinensia urine pre dan post-test tanpa pemberian kegel exercise.

Tabel 5. Perbedaan Rata-Rata Inkontinensia Urine Post-Test antara Kelompok Perlakuan dan Kelompok Kontrol

\begin{tabular}{crrrr}
\hline Kelompok & N & Mean & SD & p value \\
\hline Perlakuan & 17 & 9,29 & 2,779 & \\
Kontrol & 17 & 11,88 & 1,996 & 0,004 \\
\hline
\end{tabular}

Berdasarkan tabel 5 di atas, hasil uji independent t-test didapatkan mean post-test inkontinensia urine pada kelompok experiment adalah 9,29 dengan standar deviasi 2,779. Mean post test inkontinensia urine kelompok kontrol adalah 11,88 dengan standar deviasi 1,996. Adapun hasil uji statistik menggunakan independent t-test didapatkan $p$ value $0,004<$ 
$\alpha$ 0,05. Hal ini dapat disimpulkan bahwa terdapat pengaruh yang signifikan Kegel exercise terhadap inkontinensia urine pada kelompok perlakuan dengan dan kelompok kontrol.

\section{PEMBAHASAN}

\section{Karakteristik Responden}

\section{Usia}

Berdasarkan hasil penelitian didapatkan bahwa usia responden terbanyak adalah pada rentang usia $>35$ tahun yaitu sebanyak 19 responden $(55,9 \%)$. WHO (2014) menjelaskan bahwa usia yang dianggap paling aman untuk menjalani kehamilan dan persalinan adalah usia 20 hingga 35 tahun karena kehamilan dan melahirkan diusia $<20$ tahun atau $>35$ tahun merupakan yang berisiko tinggi. Kehamilan dan melahirkan pada usia muda $(<20)$ merupakan kondisi dimana ibu masih dalam proses pertumbuhan sehingga asupan makanan lebih banyak digunakan untuk mencukupi kebutuhan ibu, kehamilan dan melahirkan pada usia $>21$ tahun merupakan kondisi wanita sudah matang baik dari segi fisik maupun psikologis, sehinggga siap untuk menghadapi kehamilan dan persalinan, sebaliknya dengan umur $>35$ tahun dianggap sudah terlalu tua untuk menanggung beban kehamilan, serta hormon didalam tubuh juga semakin menurun (Sistriani, 2008).

Umur merupakan salah satu faktor risiko terjadinya inkontinensia urine. Peningkatan usia akan menyebabkan penurunan tonus otot dasar panggul yang dapat menyebabkan terganggunya kontrol otot sfingter eksterna uretra dan otot kandung kemih (Crever \& Hirnle, 2007). Hal inilah yang menyebabkan usia menjadi salah satu penyebab terjadinya inkontinensia urine. Hatem (2007) menyatakan bahwa wanita yang berusia diatas 35 tahun mempunyai risiko 2 kali lebih tinggi dibandingkan wanita berusia dibawah 35 tahun bukan hanya terhadap inkontinensia urine tetapi juga terhadap komplikasi yang lain seperti perdarahaan dan prolapse uteri.

\section{Pendidikan}

Sebagian besar pendidikan responden adalah pendidikan dasar dan menengah dengan jumlah masing-masing 41,2\%. Notoatmodjo (2012) menjelaskan bahwa pendidikan merupakan salah satu faktor yang mendukung peningkatan pengetahuan yang berkaitan dengan daya serap informasi. Semakin tinggi pendidikan seseorang maka semakin baik pula pengetahuannya dibandingkan dengan seseorang dengan tingkat pendidikan rendah. Orang yang memiliki pendidikan tinggi diasumsikan lebih mudah menyerap informasi begitupun sebaliknya.

Pengetahuan tentang inkontinensia urine belum banyak diperoleh oleh responden itu sendiri, dan sudah ada juga yang mendapat informasi dari petugas kesehatan. Hal ini dikarenakan tingkat pengetahuan pasien yang masih rendah dan cenderung merasa malu dengan kondisi yang dimiliki responden untuk bertanya dan menceritakan kepada orang lain. Rendahnya tingkat pendidikan dan menurunnya pola pikir seseorang akan berpengaruh terhadap persepsi seseorang terhadap inkontinensia urine dengan kecil harapan bisa meminimalisir inkontinensia urine yang dirasakannya dengan pengetahuan yang dimilikinya (Maritalia, 2012).

\section{Pekerjaan}

Hasil penelitian berdasarkan karakteristik jenis pekerjaan sebagian besar adalah ibu rumah tangga (73,5\%). Penelitian ini sejalan dengan penelitian yang telah dilakukan oleh Hidayat (2018) menunjukkan hasil bahwa sebagian besar responden memiliki pekerjaan sebagai ibu rumah tangga $(70 \%)$. 
Pekerjaan responden akan mempengaruhi kegiatan fisik responden, dimana pada penelitian ini rata-rata ibu rumah tangga melakukan aktivitas fisik seperti menyapu, memasak dan mencuci dan melakukan kegiatan aktivitas fisik lainnya yang berat. Hal ini sesuai dengan penelitian Mustamin (2010) yang menyatakan bahwa sebagian besar subjek melakukan aktivitas fisik yang berat, melakukan aktivitas rutin sebagai ibu rumah tangga misalnya memasak, mencuci, membersihkan rumah, cuci piring, dan aktivitas berat seperti mengangkat-angkat galon dan lainnya.

Hal ini dapat menyebabkan ibu rumah tangga mengalami inkontinensia urine, dikarenakan melakukan aktivitas yang berat dan mengangkat benda berat. Kondisi ini dapat mempengaruhi terjadinya penurunan kandung kemih oleh ibu sehingga terjadi inkontinensia urine serta tidak pernahnya melatih otot dasar panggul dan dipengaruhi oleh riwayat melahirkan secara normal dengan melahirkan anak lebih dari satu. Pinem (2012), menyatakan bahwa ibu yang melahirkan pervaginam mengalami masalah inkontinensia urine serta ditemukan bahwa proporsi kejadian inkontinensia urine pada postpartum lebih tinggi pada ibu multipara dibandingkan ibu primipara.

\section{Perbedaan Rata-Rata Inkontinensia urine Sebelum dan Sesudah Kegel exercise pada Kelompok Perlakuan}

Hasil penelitian membuktikan bahwa terdapat pengaruh kegel exercise terhadap inkontinensia urine pada ibu post partum multipara. Berdasarkan penelitian pada 17 orang kelompok perlakuan didapatkan bahwa mayoritas inkontinensia urine adalah pada kategori inkontinensia sedang dan parah, tetapi setelah dilakukan intervensi Kegel exercise selama 3 hari berturut-turut sebagian besar responden mengalami penurunan inkontinensia menjadi inkontinensia urine sedang dan ringan.

Penelitian ini sejalan dengan hasil penelitian Hidayat (2018), bahwa terdapat pengaruh senam Kegel exercise terhadap penurunan tingkat inkontinensia urine pada ibu post-partum dengan nilai $p$ value $0,000<\alpha$ 0,05 . Perubahan yang terjadi pada hampir seluruh organ tubuh termasuk organ berkemih adalah dampak dari proses post-partum, lemahnya otot dasar panggul yang menyangga kandung kemih dan sfingter uretra. Timbulnya kontraksi yang tidak terkontrol pada kandung kemih menimbulkan rangsangan untuk berkemih sebelum waktunya dan pengosongan kandung kemih yang tidak sempurna. Hal ini menyebabkan gangguan eliminasi urine (inkontinensia urine). Pemberian Kegel exercise bisa mencegah bahkan menyembuhkan gangguan eliminasi urine (inkontinensia urine).

\section{Perbedaan Rata-Rata Frekuensi Inkontinensia Urine Post-Test antara Kelompok Perlakuan dan Kelompok Kontrol}

Hasil penelitian menunjukkan bahwa mean post-test inkontinensia urine pada kelompok perlakuan adalah 9,29 dengan standar deviasi 2,779. Mean post test inkontinensia urine kelompok kontrol adalah 11,88 dengan standar deviasi 1,996. Adapun hasil uji statistik didapatkan $p$ value $0,004<\alpha$ 0,05. Penelitian ini sejalan Melania (2013), menyatakan bahwa terdapat perbedaan nilai rata-rata inkontinensia urine post-test setelah dilakukan intervensi antara kelompok perlakuan dan kontrol.

Adanya perbedaan yang bermakna pada nilai post test kelompok perlakuan dan kontrol disebabkan karena adanya Kegel exercise yang merupakan senam untuk memperkuat otot-otot dasar panggul terutama otot pubococcygeal sehingga seorang wanita 
dapat memperkuat otot-otot saluran kemih. Hal ini berguna saat proses persalinan agar tidak terjadi inkontinensia urine (Widianti \& Proverawati, 2010). Penelitian ini juga sejalan dengan Hidayat (2018) yangmenyatakan bahwa pemberian Kegel exercise sangat berpengaruh untuk mengurangi tingkat inkontinensia urine. Perubahan yang terjadi pada hampir seluruh organ tubuh termasuk organ berkemih adalah dampak dari proses post-partum, lemahnya otot dasar panggul yang menyangga kandung kemih dan sfingter uretra, timbulnya kontraksi yang tidak terkontrol pada kandung kemih menimbulkan rangsangan untuk berkemih sebelum waktunya dan pengosongan kandung kemih yang tidak sempurna. Semua ini menyebabkan gangguan eliminasi urine (inkontinensia urine). Pemberian kegel exercise bisa mencegah bahkan mengatasi inkontinensia urine (Hidayat, 2018).

\section{KESIMPULAN DAN SARAN}

Penelitian ini membuktikan bahwa Kegel exercise berpengaruh terhadap inkontinensia urine pada ibu postpartum multipara, dan terdapat pengaruh Kegel exercise terhadap inkontinensia urine pada kelompok experiment dengan diberikan Kegel exercise dan kelompok kontrol tanpa diberikan Kegel exercise dengan $p$ value 0,004 ( $p<$ $0,05)$.

Institusi kesehatan diharapkan dapat menjadikan Kegel exercise sebagai salah satu terapi non farmakologi untuk mengurangi ketidaknyamanan terutama inkontinensia urine pada ibu postpartum multipara. Hasil penelitian ini dapat dijadikan bahan dalam pembelajaran khususnya dalam bidang keperawatan maternitas dalam upaya pemenuhan rasa nyaman terutama pada ibu postpartum dalam mengendalikan kebocoran urine. Ibu postpartum yang mempunyai masalah Inkontinensia urine diharapkan untuk dapat mengaplikasikan kegel exercise ini secara teratur untuk mengurangi inkontinensia urine serta bisa mengatasi dan mencegah terjadinya inkontinensia urine pada periode postpartum berikutnya. Penelitian lebih lanjut dapat dilakukan dengan meneliti pengaruh Kegel exercise terhadap masalah kesehatan lain.

\section{DAFTAR PUSTAKA}

Achirda, N. (2016). Kombinasi biofeedback dan Kegel exercise lebih baik meningkatkan otot dasar panggul pada inkontinensia urine tipe stress pasca partus normal. Universitas Udayana.

Bobak, I. M., Lowdermilk, D. L., \& Jensen, M. D. (2011). Buku keperawatan maternitas. Jakarta: Buku kedokteran EGC.

Ambarwati. (2010). Asuhan kebidanan nifas. Yogyakarta: Nuha Medika.

Departemen Kesehatan Republik Indonesia. (2016). Data kesehatan di Indonesia. http://www.depkes.go.id. Diakses pada tanggal 20 mei 2019.

Cafkaytar. (2014). Pengaruh Latihan kegel berbasis rumah dalam menurunkan stress urine incontinencia dan mised urine incontinencia. Sumatera utara: Universitas Sumatera Utara.

Crever \& Himle. (2007). Basic nursing seventh edition. St. Louis Missouri: Mosby Elsevier.

Hatem. (2007). Asuhan keperawatan maternitas. Yogyakarta: Nuha Medika.

Hidayat, A. (2018). Pengaruh pemberian Kegel exercise terhadap tingkat inkontinensia urine pada ibu post partum. Universitas Mojokerto.

Karjoyo, J. D. (2017). Pengaruh senam Kegel terhadap frekuensi inkontinensia urine pada lanjut usia. Universitas Sam Ratulangi. 
Maritalia, D. (2012). Asuhan kebidanan nifas dan menyusui. Yogyakarta: Pustaka Belajar.

Melania, E. (2013). Efektifitas kegel exercise terhadap pencegahan inkontinensia urin pada ibu postpartum pervaginam di Rumah Sakit Bhayangkara Polda Kalbar. Jurnal Keperawatan, 1(1). doi: 10.26418/jpn.v1i1.3043

Mustamin. (2010). Intranatal care asuhan kebidanan pada persalinan. Yogyakarta: Pustaka Pelajar.

Notoatmodjo, S. (2012). Ilmu perilaku kesehatan. Jakarta: Rineka Cipta.

Pinem L, H. (2012). Efektivitas paket latihan mandiri terhadap pencegahan inkontinensia urine pada ibu postpartum. Universitas Indonesia.

Please, C. (2017). Kegel exercise for men. Diperoleh dari https://www.uclahealth.org/urology/w orkfiles/Prostate_Cancer/Kegel_Exerc ises_for_Men.pdf

Purnomo, B. (2011). Dasar-dasar urologi edisi 2. Malang: CV Infomedia.

Puskesmas Rejosari. (2017). Sasaran program kesehatan Puskesmas Rejosari Pekanbaru tahun 2017. Pekanbaru: Puskesmas Rejosari Pekanbaru.

Sistiarani, C. (2008). Faktor maternal dan kualitas pelayanan antenatal yang berisiko terhadap kejadian berat badan lahir rendah (bblr) studi pada ibu yang periksa hamil ke tenaga kesehatan dan melahirkan di RSUD Banyumas. Diperoleh dari https://core.ac.uk/download/pdf/11716 687.pdf

Stenley \& Barea. (2007). Buku ajar keperawatan gerontik. Edisi 2. Jakarta: EGC.

Widianti \& Proverawati (2010). Senam kesehatan. Yogjakarta: Nuha medika.
World Health Organisation. (2014). Pregnancy. Diperoleh dari http://www.who.int/topics/pregnancy

World Health Organization. (2016). Maternal and newborn health. Diperoleh dari http://www.who.int/reproductivehealth/MNBH/index.htm. 